\title{
Expression of UPAR mRNA in peripheral blood is a favourite marker for metastasis in gastric cancer cases
}

\author{
Y Kita ${ }^{1,2}$, T Fukagawa ${ }^{3}$, K Mimori', Y Kosaka', K Ishikawa', T Aikou ${ }^{2}$, S Natsugoe ${ }^{2}$, M Sasako ${ }^{3}$ and M Mori, ${ }^{*, 1}$ \\ 'Department of Surgery, Medical Institute of Bioregulation, Kyushu University, 4546, Tsurumihara, Beppu 874-0838, Japan; ${ }^{2}$ Department of Surgical \\ Oncology and Digestive Surgery, Field of Oncology, Course of Advanced Therapeutics, Kagoshima University, Graduate School of Medical and Dental \\ Science, Kagoshima University, 8-35-I, Sakuragaoka, Kagoshima 890-8520, Japan; ${ }^{3}$ Gastric Surgery Division, National Cancer Center Hospital, 5-I - I \\ Tsukiji, Chuo-ku 104-0045, Japan
}

\begin{abstract}
Urokinase-type plasminogen activator receptor (UPAR) plays a central role in the plasminogen activation cascade and participates in extracellular matrix degradation, cell migration and invasion. We evaluated the expression level of uPAR mRNA and the presence of isolated tumour cells (ITCS) in bone marrow (BM) and peripheral blood (PB) in gastric cancer patients and clarified its clinical significance. We assessed specific UPAR mRNA expression by quantitative real-time reverse transcriptase- polymerase chain reaction (RT-PCR) in BM and PB in 846 gastric cancer patients as well as three epithelial cell markers, carcinoembryonic antigen (CEA), cytokeratin (CK)- 19 and CK-7. The UPAR mRNA expression in bone marrow and peripheral blood expressed significantly higher than normal controls $(P<0.000 \mathrm{I})$. The UPAR mRNA in BM showed concordant expression with the depth of tumour invasion, distant metastasis, and the postoperative recurrence $(P=0.015,0.044$ and 0.010 , respectively); whereas in $P B$, we observed more intimate significant association between UPAR expression and clinicopathologic variables, such as depth of tumour invasion, the distant metastasis, the venous invasion and the clinical stage $(P=0.009,0.002,0.039$ and 0.008 , respectively). In addition, the uPAR mRNA expression in PB was an independent prognostic factor for distant metastasis by multivariate analysis. We disclosed that it was possible to identify high-risk patients for distant metastasis by measuring uPAR mRNA especially in peripheral blood at the timing of operation in gastric cancer patients.
\end{abstract}

British Journal of Cancer (2009) I 00, 153-159. doi:10.1038/sj.bjc.6604806 www.bjcancer.com

Published online 2 December 2008

(c) 2009 Cancer Research UK

Keywords: gastric cancer; circulating tumour cells; peripheral blood; bone marrow; urokinase-type plasminogen activator receptor (UPAR); metastasis

The presence of isolated tumour cells (ITCs) in bone marrow (BM) and peripheral blood (PB) is missed by conventional imaging system, and ITCs expected to be a determinant factor of subsequent formation of micrometastasis. The search for ITCs in patients with curatively resected tumours is of considerable importance, because early dissemination of tumour cells is one of the leading causes of relapse at the distant site and of death from cancer (Hellman, 1997). In spite of large number of studies to determine the clinicopathologic significance of ITCs in human solid carcinomas, much efforts have been made and found no definitive evidence to conclude these controversial issues, such as the way to identify ITCs and the appropriate biologic marker to predict the metastatic ability of gastric cancer cells (Heiss et al, 1995, 1997, 2002; Jauch et al, 1996; Hardingham et al, 2000; Lecomte et al, 2002; Natsugoe et al, 2003; Ikeguchi and Kaibara, 2005).

To identify ITCs in BM or PB, a bunch of molecular targets, such as CEA, CK7, CK18, CK18, CK19 and MAGE families have been

\footnotetext{
*Correspondence: Dr M Mori;

E-mail: mmori@tsurumi.beppu.kyushu-u.ac.jp

Received I July 2008; revised I| November 2008; accepted I|

November 2008; published online 2 December 2008
}

applied and examined whether those genes were applicable to detect ITCs. Above all candidates, CEA and cytokeratin (CK), epithelial cell surface markers were frequently used to be applied to detect ITCs instead of the direct detection of cancer cells in those ITC studies. However, our recent study disclosed that ITCs in $\mathrm{BM}$ and $\mathrm{PB}$ from gastric cancer could not be specified by the presence of CEA and/or CKs by RT-PCR, because those genes were detected ubiquitously among stages of 810 patients of gastric cancer. Therefore, we must identify a favourite marker to detect ITCs specifically as well as to predict metastasis precisely. In the current study, we focused on urokinase-type plasminogen activator receptor $(U P A R)$ gene as a target molecule to detect isolated tumour cells in blood and bone marrow. This is because that in gastric cancer, several reports showed clearly that uPAR expression in bone marrow (BM) is one of the useful prognostic marker by immunohistochemistry (Heiss et al, 1995, 2002; Allgayer et al, 1997). However, there are no earlier reports of the clinical significance of the gene expression level of $U P A R$ with quantitative RT - PCR assay that enabled us to examine objectively and repeatedly. Therefore, the aim of the current study was to evaluate the expressions of $U P A R$ mRNA in bone marrow and peripheral blood in more than 800 cases of gastric cancer and to define its clinicopathologic and prognostic significance in gastric cancer patients. 


\section{MATERIALS AND METHODS}

\section{Gastric cancer cases}

A total of 846 gastric cancer patients who underwent surgical treatment in the National Cancer Center Hospital, Japan from 2001 to 2004 were studied. Clinical stages and pathological features of primary tumours were defined according to the classification of the International Union Against Cancer (Sobin and Fleming, 1997). There were 567 male and 279 female patients with average age 61.5, and a range of 27-87 years. None of these patients underwent endoscopic mucosal resection or palliative resection. Written informed consent had been obtained from all patients.

\section{Normal controls}

For normal negative controls, both peripheral blood and bone marrow were collected from 25 patients having no malignancy from April 2000 to March 2003. This group included 16 cases of gallstone, three cases of common bile duct stone, and six cases of incisional hernia. We extracted BM from the sternum of patients without malignancies but had operations under general anaesthesia.

\section{Bone marrow and blood samples}

Aspiration of both $\mathrm{BM}$ and $\mathrm{PB}$ was conducted immediately prior to operation under general anaesthesia. The aspirated BM was obtained from the sternum using a bone marrow aspiration needle (MDTECH, Gainesville, FL, USA). Peripheral blood was obtained through a venous catheter. The $1 \mathrm{ml}$ of both $\mathrm{BM}$ and $\mathrm{PB}$ samples was discarded to avoid the contamination of the epidermal cells (Iinuma et al, 2006). Each $1 \mathrm{ml}$ sample of $\mathrm{BM}$ and $\mathrm{PB}$ was immediately mixed with $4 \mathrm{ml}$ of ISOGEN-LS (Nippon Gene, Toyama, Japan) and stored at $-80^{\circ} \mathrm{C}$ until RNA extraction.

\section{Total RNA extraction and first strand cDNA synthesis}

Total RNA was according to the ISOGEN-LS manufacturer's protocols. All the clinical samples obtained in National Cancer Center Hospital were sent to our institute. The reverse transcriptase reaction (RT) was performed as described earlier (Mori et al, 1995; Masuda et al, 2002). The first strand cDNA was synthesized from $2.7 \mu \mathrm{g}$ of total RNA in a $30 \mu \mathrm{l}$ reaction mixture containing $5 \mu \mathrm{l}$ $5 \times \mathrm{RT}$ reaction buffer (BRL, Gaithersburg, MD, USA), $200 \mu \mathrm{M}$ $\mathrm{dNTP}, 100 \mu \mathrm{M}$ solution of random hexadeoxynucleotide mixture, 50 units of Rnasin (Promega, Madison, WI, USA), $2 \mu \mathrm{l}$ of $0.1 \mathrm{M}$ dithiothreitol, and $100 \mathrm{U}$ of Molony leukaemia virus RT (BRL). The mixture was incubated at $37^{\circ} \mathrm{C}$ for $60 \mathrm{~min}$, heated to $95^{\circ} \mathrm{C}$ for $10 \mathrm{~min}$, and then chilled on ice.

\section{Primers and probes for detecting ITCs and $U P A R$ expression}

Quantitative RT-PCR methodology was designed to optimise the specificity and fidelity of the assay. The Kyushu University group had previously investigated the expression of seven representative molecular markers (carcinoembryonic antigen (CEA), CK-7, CK18, CK-19, CK-20, mammaglobin and mucin (MUC)-1) in 27 cancers and eight non-epithelial cell lines using quantitative RT - PCR. The expression levels of $C K-7$ and $C K-19$ showed high sensitivity and specificity for the identification of gastric cancer cells in comparison with the other markers (Masuda et al, 2005). Those epithelial cell markers have been widely used as target genes for the detection of ITCs (Mori et al, 1996, 1998; Yamaguchi et al, 2000; Bessa et al, 2003; Sadahiro et al, 2005). Thus, CEA, CK-7, CK-19 and GAPDH were studied by quantitative RT-PCR in all 846 patients (Mimori et al, 2008). Isolated tumour cells were considered to be 'present' when any single marker was positive.
The reverse transcriptase reaction was performed as described elsewhere (Mimori et al, 2008). We performed real-time quantitative RT-PCR using a LightCycler instrument (Roche Diagnostics, Manheim, Germany) to detect ITCs in peripheral blood and/or bone marrow as the previous study.

Moreover, a $U P A R$-specific oligonucleotide primer was designed as follows: sense, $5^{\prime}$-TGAATCAATGTCTGGTAGC- $3^{\prime}$ and antisense, $5^{\prime}$-TGGTTACAGCCACTTTTAGT- $3^{\prime}$. The donor and acceptor probe sequences for $U P A R$ identification were $5^{\prime}$-GCTATATGGTA AGAGGCTGTGCAACCGCCT-fluorescein and $5^{\prime}$-LC-Red640-AAT GTGCCAACATGCCCACCTGGG T -phosphorylation. Besides, $u P A$ primers were as follows: forward primer; CTGTGACTGTC TAAATGGAGG; and the reverse primer; GACGATGTAGTCCT CCTTCTT (Nielsen et al, 2004).

Preliminary trials were undertaken to assure that results were accurate and reliable. We utilised highly specific hybridisation probes and primers to maintain high specificity for target genes and thereby reduce false positive outcomes.

\section{RT - PCR conditions}

PCR amplification was performed using a quantitative fluorescence LightCycler $^{\mathrm{TM}}$ (Roche Diagnostics, Mannheim, Germany) in a $20 \mu \mathrm{l}$ reaction mixture containing $2 \mu \mathrm{l}$ of LightCyclert FastStart DNA Master Hybridisation Probes (Roche, Diagnostics, Tokyo, Japan), $4.0 \mu \mathrm{l} \mathrm{MgCl}_{2}, 0.3 \mu \mathrm{M}$ sense and antisense primers, $0.2 \mu \mathrm{M}$ fluorescent probe, $0.2 \mu \mathrm{m}$ LC-Red probe and $5 \mu \mathrm{l}$ of undiluted template cDNA in LightCyclert capillaries (Roche Diagnostics, Tokyo, Japan). The amplification of CEA profile consisted of one cycle at $95^{\circ} \mathrm{C}$ for $10 \mathrm{~min}$ (denaturation) followed by 45 cycles of $95^{\circ} \mathrm{C}$ for $15 \mathrm{~s}, 56^{\circ} \mathrm{C}$ for $15 \mathrm{~s}$ and $72^{\circ} \mathrm{C}$ for $13 \mathrm{~s}$. The amplification of CK-7 profile consisted of one cycle at $95^{\circ} \mathrm{C}$ for $10 \mathrm{~min}$ (denaturation) followed by 50 cycles of $95^{\circ} \mathrm{C}$ for $10 \mathrm{~s}, 60^{\circ} \mathrm{C}$ for $12 \mathrm{~s}$ and $72^{\circ} \mathrm{C}$ for $10 \mathrm{~s}$. The amplification of $C K-19$ profile consisted of one cycle at $95^{\circ} \mathrm{C}$ for $10 \mathrm{~min}$ (denaturation) followed by 45 cycles of $95^{\circ} \mathrm{C}$ for $10 \mathrm{~s}, 60^{\circ} \mathrm{C}$ for $15 \mathrm{~s}$ and $72^{\circ} \mathrm{C}$ for $16 \mathrm{~s}$. The amplification of $u P A R$ profile consisted of one cycle at $95^{\circ} \mathrm{C}$ for $10 \mathrm{~min}$ (denaturation) followed by 40 cycles of $95^{\circ} \mathrm{C}$ for $10 \mathrm{~s}, 62^{\circ} \mathrm{C}$ for $15 \mathrm{~s}$ and $72^{\circ} \mathrm{C}$ for $8 \mathrm{~s}$. The amplification of GAPDH profile consisted of one cycle at $95^{\circ} \mathrm{C}$ for $10 \mathrm{~min}$ (denaturation) followed by 40 cycles of $95^{\circ} \mathrm{C}$ for $15 \mathrm{~s}, 60^{\circ} \mathrm{C}$ for $15 \mathrm{~s}$ and $72^{\circ} \mathrm{C}$ for $13 \mathrm{~s}$. The amplification of uPA was as follows: $5 \mathrm{~min}$ at $94^{\circ} \mathrm{C}, 27$ cycles of $1 \mathrm{~min}$ at $94^{\circ} \mathrm{C}, 1 \mathrm{~min}$ at $56^{\circ} \mathrm{C}$, $1 \mathrm{~min}$ at $72^{\circ} \mathrm{C}$, then $10 \mathrm{~min}$ at $72^{\circ} \mathrm{C}$ (Nielsen et al, 2004). Real-time PCR was monitored by measuring fluorescent signals at the end of the annealing phase for each cycle. All primers and probes were synthesized and purified by reverse phase high-performance liquid chromatography and the optimal reagent concentrations and PCR cycling conditions were established and each run of RT-PCR included positive controls synthesized from plasmids by the Nippon Gene Research Laboratories (Sendai, Japan). Real-time RT-PCR assays were repeated in triplicate and adapted the mean value. Quantification data were analysed using the Light-Cycler ${ }^{\mathrm{TM}}$ software (Roche Diagnostics, Tokyo, Japan).

\section{Data analysis}

A standard curve was prepared with 200-20000 copies of purified plasmids containing $C E A, C K-7, C K-19, u P A R$ and $G A P D H$. After proportional baseline adjustment, the fit point method was employed to determine the cycle in which the log-linear signal was first distinguishable from the baseline, and then that cycle number was used as a crossing-point value (Marutsuka et al, 2003). The standard curve was produced by measuring the crossing point of each standard value and plotting them against the logarithmic value of concentrations. Those concentrations were calculated by plotting their crossing points against the standard curve. 

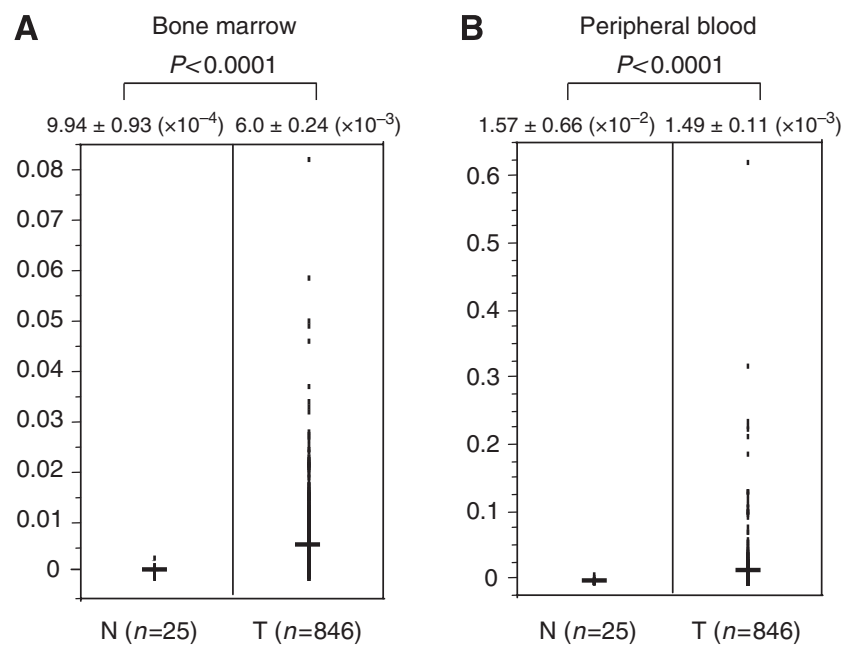

Figure I Comparison of UPAR mRNA expression between control gastric cancer patients in bone marrow $(\mathbf{A})$ and peripheral blood (B). Horizontal lines indicate the mean expression levels in control and gastric cancer patients. In bone marrow and peripheral blood, the value of the UPAR expression of gastric cancer patients was significantly higher $(P<0.000 \mathrm{I})$ than those of control cases. The $P$-value was calculated by a student's t-test.

Expression of CEA, CK-7, CK-19 and $U P A R$ was adjusted in each case for GAPDH expression. We set cutoff values for those expression ratios (CEA/GAPDH, CK-7/GAPDH, CK-19/GAPDH, $u P A R / G A P D H)$ as the highest value for each marker in 25 normal controls. We distributed high level as 'positive' and low level as 'negative' than the cutoff value. For continuous variables, the data were expressed as the mean \pm s.d. Statistical analysis of group differences was performed using the $\chi^{2}$ test and the Student's $t$-test. Logistic regression model was used to identify the independent predictors of distant metastasis. All tests were analysed using JMP software (SAS Institute Inc., Cary, NC, USA). Statistical significance was determined as $P$-value from two-sided tests of less than 0.05 .

\section{RESULTS}

\section{Expression of $U P A R$ mRNA in BM and PB of gastric cancer patients}

In $\mathrm{BM}$, the value of the $U P A R$ expression of gastric cancer patients $\left(6.0 \pm 0.24\left(\times 10^{-3}\right)\right)$ was significantly higher $(P<0.0001)$ than those of control cases $\left(9.94 \pm 0.93\left(\times 10^{-4}\right)\right)$, as shown in Figure 1 . In $\mathrm{PB}$, the value of the $U P A R$ expression of gastric cancer patients $\left(1.49 \pm 0.11\left(\times 10^{-2}\right)\right)$ was also significantly higher $(P<0.0001)$ than those of control cases $\left(1.57 \pm 0.66\left(\times 10^{-3}\right)\right)$.

\section{Clinical magnitude of $U P A R$ expression in gastric cancer patients}

The correlations between the results for the $u P A R$ mRNA level and clinicopathologic factors are summarised in Table 1 . Using each cutoff value, $431(50.9 \%)$ and $404(47.8 \%)$ of 846 patients were estimated to be positive for $U P A R$ mRNA in $\mathrm{BM}$ and $\mathrm{PB}$, respectively.

In $\mathrm{BM}$, the significantly higher population of the $U P A R$ mRNApositive cases belongs to the following clinical subgroups: invasion deeper than the muscularis propria $(P=0.015)$, perioperative overt metastases (including liver and/or lung and/or distant lymph node metastasis, $P=0.044)$ and postoperative recurrence $(P=0.010)$

In $\mathrm{PB}$, the higher expression was observed significantly in subgroup invasion deeper than the muscularis propria $(P=0.009)$, perioperative overt metastases $(P=0.002)$, venous invasion $(P=0.039)$, and the clinical stage $(P=0.008)$.

\section{Multivariate analysis for distant metastasis}

Univariate and multivariate logistic regression analyses were performed on cases with distant metastasis (Table 2). Univariate regression analysis showed that the following factors were significantly associated with distant metastasis: histological grade, tumour size, lymph node metastasis, lymphatic invasion, venous invasion and $U P A R$ mRNA expressions in $\mathrm{BM}$ and $\mathrm{PB}(P<0.05)$, respectively. Multivariate regression analysis indicated that $u P A R$ mRNA high expression group in $\mathrm{PB}$ (relative risk (RR); 1.85, $95 \%$ confidence interval $(\mathrm{CI}) ; 1.08-3.23, P=0.03)$ was an independent predictor for distant metastasis next to the incidence lymph node metastasis (RR; 6.50, $95 \%$ CI; 2.99-15.77, $P<0.0001$ ) and depth of tumour invasion (RR; 28.2, 95\% CI; 14.3-70.0, $P<0.0001$ ).

\section{The comparison of $U P A$ and $U P A R$ expression in representative gastric cancer cases}

The potential importance of UPAR for the development of minimal residual disease in solid cancer has been focused on for recent two decades; however, several studies revealed that the relevance of a ligand for $U P A R, u P A$ in mediating tumour-associated proteolysis, invasion and metastasis together with $U P A R$ expression (Andreasen et al, 2000). We examined $U P A$ expression in bone marrow and peripheral blood in representative 83 cases of gastric cancer, including 18 cases of liver and/or lung metastasis, and 12 cases of recurrence of disease among 846 cases of gastric cancer. As we showed in Table 3, we found that $u P A$ expression in bone marrow from gastric cancer is correlated with the incidence of lymph node metastasis and recurrence of gastric cancer cases as $U P A R$ expression.

\section{The clinical significance of both positive ITCs and positive UPAR expression}

We identified 66 cases out of $846(7.8 \%)$ that were positive for expression of CEA in bone marrow, whereas $108(12.7 \%)$ were positive in peripheral blood. As for CK-7, 71 patients $(8.4 \%)$ and 147 cases $(20.6 \%)$ were positive in bone marrow and in peripheral blood, respectively. Cytokeratin-19 expression was detected in bone marrow in 153 cases $(18.1 \%)$ and in 251 cases $(29.7 \%)$ in peripheral blood. Gastric cancer cases with positive expression of any one of the three markers were defined as ITC-positive in bone marrow or peripheral blood. As outlined above, ITCs were detected in $260(30.7 \%)$ cases in bone marrow and $417(49.3 \%)$ cases in peripheral blood.

Moreover, we extracted 126 cases (14.9\%) in BM and 200 cases $(23.6 \%)$ in $\mathrm{PB}$ of positive ITCs and positive $U P A R$ expression cases. Table 4 shows the clinicopathologic data and positive ITCs and positive uPAR cases from the 846 gastric cancer patients. In BM, the incidence of lymph node metastasis was significantly higher $(P=0.012)$ in the both positive group (65 of $126,51.6 \%)$ than in the other group (285 of $720,39.6 \%)$, and the incidence of lymphatic invasion was significantly higher $(P=0.009)$ in the both positive group (67 of 126,53.2\%) than in the other group (293 of $720,40.7 \%)$. Moreover, the clinical stage was significantly higher $(P=0.024)$ in the both positive group (42 of $126,33.3 \%)$ than in the other group $(170$ of $720,23.4 \%)$. In $\mathrm{PB}$, there was no significance between the both positive group and the other group.

\section{DISCUSSION}

In this study, we examined the clinicopathologic significance of UPAR expression in BM and PB in 846 cases of gastric cancer, and found that the depth of tumour invasiveness in the primary 
Table I Relationship between uPAR expression in bone marrow and peripheral blood and clinicopathologic findings

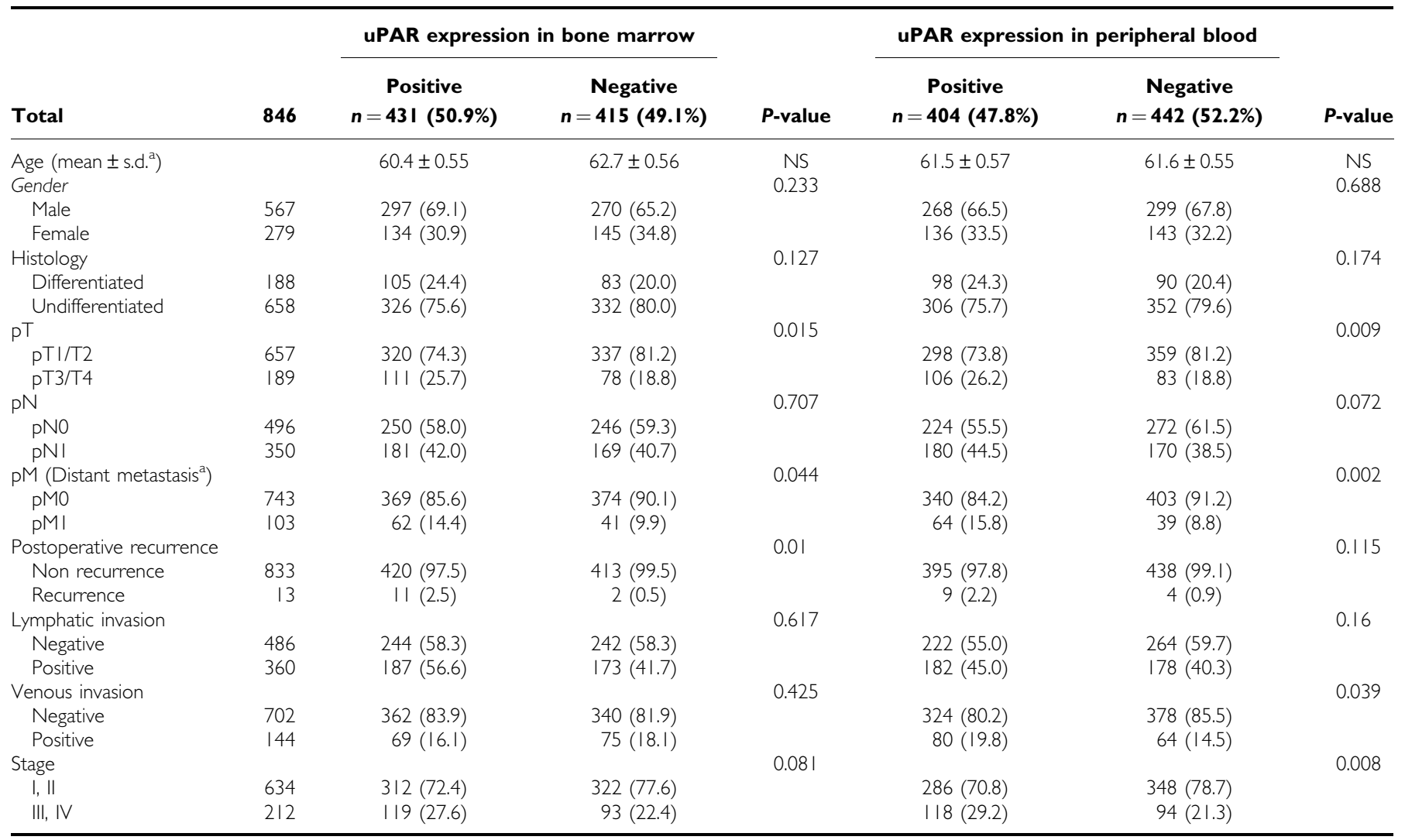

${ }^{a}$ Gastric cancer case with liver $(\mathrm{HI})$ and/or lung metastasis $(\mathrm{MI})$, cytology positive of peritoneal washes $(\mathrm{CYI})$, peritoneal dissemination $(\mathrm{P})$, and lymph node metastasis in the distant region (N3).

Table 2 Univariate and multivariate analysis for distant metastasis (logistic regression model)

\begin{tabular}{|c|c|c|c|c|c|c|}
\hline & \multicolumn{3}{|c|}{ Univariate analysis } & \multicolumn{3}{|c|}{ Multivariate analysis } \\
\hline Histological grade (Differentiated/undifferentiated) & 2.35 & $1.31-2.35$ & $<0.000$ । & 0.58 & $0.24-1.45$ & 0.239 \\
\hline PT (Depth of tumour invasion) & 49.91 & $27.36-99.07$ & $<0.0001$ & 28.17 & $14.30-60.95$ & $<0.0001$ \\
\hline pN (Lymph node metastasis) & 22.78 & $11.56-51.49$ & $<0.0001$ & 6.5 & $2.99-15.77$ & $<0.0001$ \\
\hline Lymphatic invasion & 12.12 & $6.89-23.12$ & $<0.0001$ & - & - & - \\
\hline Venous invasion & 4.55 & $2.91-7.10$ & $<0.0001$ & 1.61 & $0.90-2.88$ & 0.106 \\
\hline
\end{tabular}

tumour was significantly higher in cases of $u P A R(+)$ in $\mathrm{BM}$ and/ or PB than $U P A R(-)$ cases. In addition, we disclosed an evidence of the concordant relationship between the venous permeation in primary cancer and the incidence of $U P A R$ expression. In spite of the strong association between tumour invasiveness, the presence of $U P A R$ in $P B$ was uncovered to be much more intimate to the incidence of metastasis and could be an independent prognostic indicator for hematogenous metastasis. Therefore, we consider that $U P A R$ might play a consecutive role in cancer cells to invade into vessels and/or invading into the metastatic site. Furthermore, the clinical relevance of $U P A R$ in bone marrow was observed with the incidence of recurrence, not with the synchronous distant metastasis. There was a possible explanation which is as follows, Kook et al (1994) reported that $U P A R$ can play a role in tumour cell dormancy. They reported that a $u P A R$-antisense strategy in a human squamous carcinoma cell line resulting in a significant reduction of $U P A R$ gene expression, induced tumour cell dormancy in their study. Besides, Laufs et al (2006) described this point in the review concerning $U P A R$. Therefore, the abundant expression of $U P A R$ in bone marrow might indicate the presence of many dormant cells giving rise to recurrence in the future.

In an earlier study by Jauch et al (1996) uPAR is a glycosylphosphatidylinositol-anchored glycoprotein localised on the outer layer of the plasma membrane of cells, and it binds to its specific ligands such as urokinase-type plasminogen activator (uPA). In this study, we confirmed the concordant relationship between $U P A R$ and $U P A$ in bone marrow and peripheral blood indicating that both proteins have a synergistic role with each other in lymph node metastasis and recurrence of gastric cancer. However, uPAR activation ultimately leads to degradation of the extracellular matrix and fascinates cellular movement for tumour cells, which appears to be necessary for diverse 
Table 3 Clinicopathologic significance of UPAR and uPA expressions in bone marrow (BM) and peripheral blood (PB) from gastric cancer cases

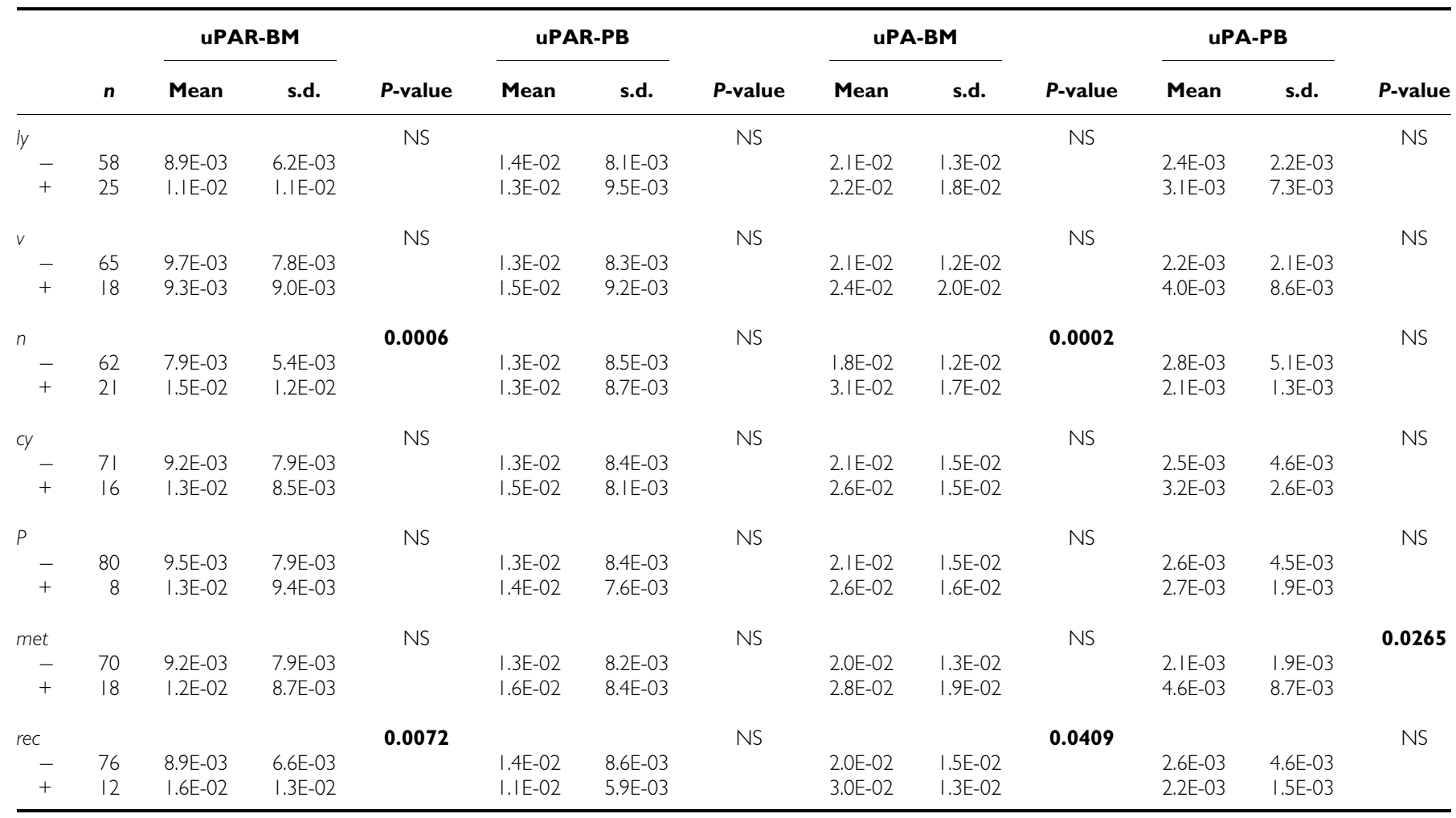

$c y=$ cytology of peritoneal washes; ly=lymphatic permiation; met = liver and/or lung metastasis; $n=$ lymph node metastasis; $p=$ peritoneal dissemination; rec = recurrence; s.d. = standard deviation; $v=$ vascular permiation. Significant differences $(P<0.05)$ were described in bold letters.

functions including local invasion and metastasis of tumour cells (Heiss et al, 1997).

Then, the second point is what is the origin of cells expressing $u P A R$ gene in BM and especially in PB. As a matter of fact, Heiss et al $(1995,1997,2002)$ reported that the gastric cancer patients with cells with uPAR protein expression by immunocytology showed significantly poorer prognosis than cases without uPAR expression by Kaplan-Meier analysis in the previous study (Jauch et al, 1996; Hardingham et al, 2000). They confirmed that uPAR protein expressing cells on the surface cells was a cancer cell by immunocytological study. Their study strongly supported the current study by quantitative RT-PCR assay that the detected $u P A R$ expression by RT-PCR should be originally from gastric cancer cells, and gastric cancer patients with cancer cells with the invasive ability especially in PB. Moreover, we additionally disclosed that cancer patients with simultaneous expression UPAR and epithelial cell markers, CEA,CK19 and CK7 showed a relatively poorer prognosis than ITCs alone. Gastric cancer cell isolated from primary cancer is circulating in the peripheral blood and bone marrow ubiquitously among whole stages (Mimori et al, 2008); however, isolated cancer cells with several potential abilities must be required to form metastasis. According to this study, we concluded that $u P A R$-expressing isolated tumour cells are important in the determination of recurrence through lymph node metastasis.

On the contrary to the hypothesis of the origin of UPAR expression in cancer cells, several studies have uncovered findings of the uPAR from host side cells in BM or PB from cancer patients. Pyke et al (1993) reported the abundant expression of UPAR in macrophage (Dubuisson et al, 2000), and Sugai et al (2004) disclosed that advances in gastric cancer cases indicated the activation of inflammatory cytokines, such as IL-10 and IL-12 from macrophages. Furthermore, Hildenbrand et al (1998) mentioned that the abundant expression of UPAR was observed in endothelial cells, which has been recently really focused on as the key player for the initial development of metastasis. Mancuso et al (2001) reported that the number of circulating endothelial cells (CECs) in $\mathrm{PB}$ from cancer patients are more than that in healthy volunteers (Beerepoot et al, 2004). Asahara et al (1997) reported that bone marrow-derived endothelial cell progenitor cells were disseminated to the neovascularisation of the cellular surface of malignant cells (Peters et al, 2005). In addition, EPC-specific gene, Id-1, was reported to be identified and its consecutive role for metastasis has been reported in the recent study. Therefore, we considered that the presence of CEC or EPC in PB should be important to form metastasis, and our current study elucidated the role of uPAR especially in PB as the independent marker for metastasis.

In this study, we concluded that the RT-PCR assay for $u P A R$ expression in $\mathrm{PB}$ can be one of the favourite tumour markers to predict DFS in gastric cancer outpatients. Then, we disclosed the abundant expression of uPAR in gastric cancer cases with invasion and with venous invasion abilities. Earlier Heiss et al distinctively disclosed that UPAR expression in BM and PB in gastric cancer is originally from cancer cells themselves (Heiss et al, 1995). However, as the clinicopathologic significance and the predictive role for metastasis is much more consecutive in UPAR in PB than in BM, uPAR might be originally expressed in endothelial (progenitor) cells as the host side reaction in gastric cancer patients. Further study will be required to address this controversial issue.

\section{ACKNOWLEDGEMENTS}

This work was supported by the following grant sponsors: CREST, Japan Science and Technology Agency (JST); Japan Society for the 
Table 4 Relationship between epithelial marker and uPAR expression in bone marrow and peripheral blood and clinicopathologic findings

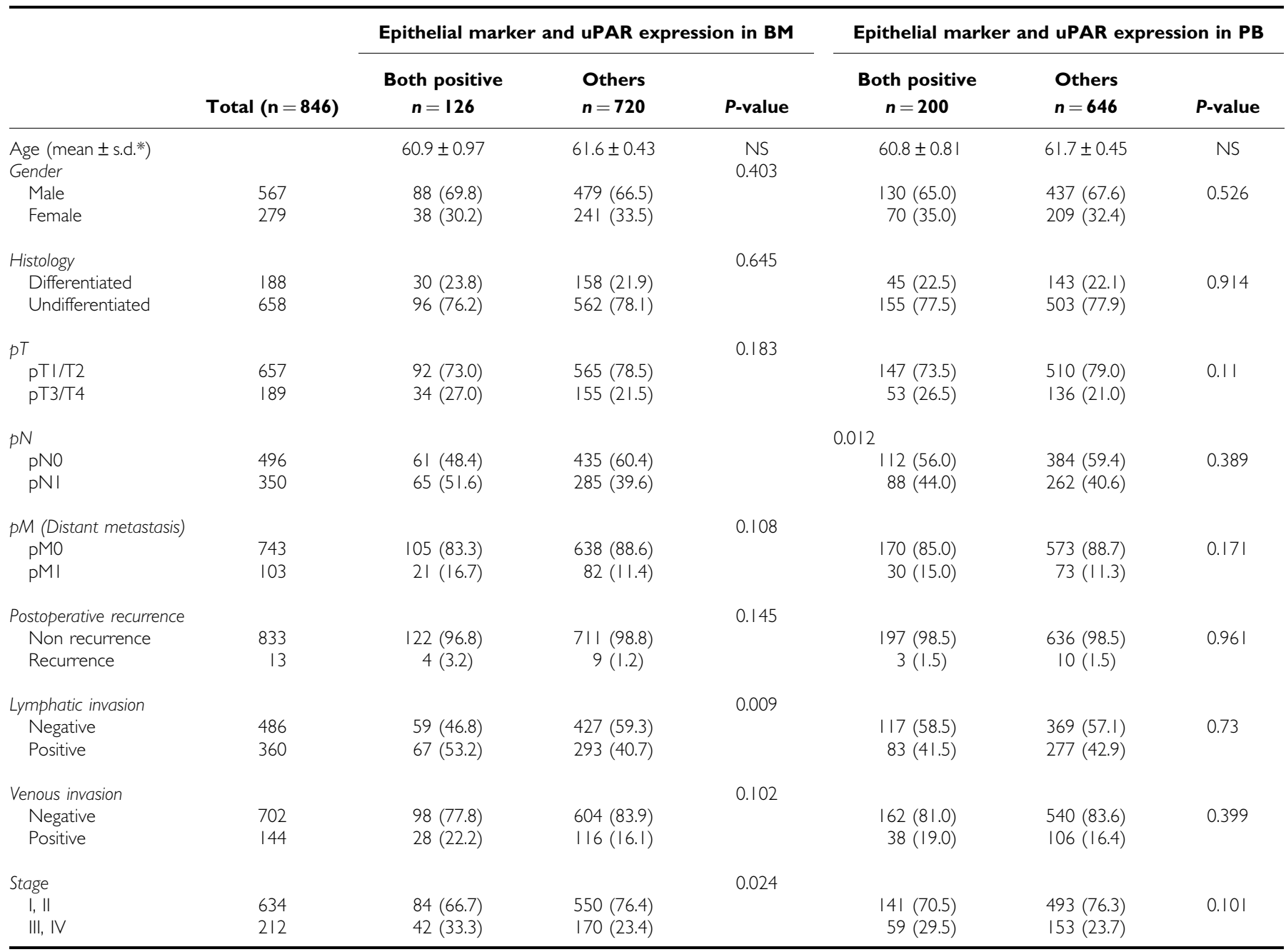

*s.d. = standard deviation.

Promotion of Science (JSPS) Grant-in-Aid for Scientific Research, Grant numbers 17109013, 17591411, 17591413, 18390367, 18590333, 18659384 and 18790964; The Ministry of Education, Culture, Sports,
Science and Technology (MEXT) Grant-in-Aid for Scientific Research on Priority Areas, Grant number 18015039; Third Term Comprehensive 10-year Strategy for Cancer Control, Grant number 16271201.

\section{REFERENCES}

Allgayer H, Heiss MM, Riesenberg R, Grutzner KU, Tarabichi A, Babic R, Schildberg FW (1997) Urokinase plasminogen activator receptor (uPA$\mathrm{R})$ : one potential characteristic of metastatic phenotypes in minimal residual tumor disease. Cancer Res 57: $1394-1399$

Andreasen PA, Egelund R, Petersen HH (2000) The plasminogen activation system in tumor growth, invasion, and metastasis. Cell Mol Life Sci 57: 25 - 40

Asahara T, Murohara T, Sullivan A, Silver M, van der Zee R, Li T, Witzenbichler B, Schatteman G, Isner JM (1997) Isolation of putative progenitor endothelial cells for angiogenesis. Science 275: 964-967

Beerepoot LV, Mehra N, Vermaat JS, Zonnenberg BA, Gebbink MF, Voest EE (2004) Increased levels of viable circulating endothelial cells are an indicator of progressive disease in cancer patients. Ann Oncol 15: $139-145$

Bessa X, Pinol V, Castellvi-Bel S, Piazuelo E, Lacy AM, Elizalde JI, Pique JM, Castells A (2003) Prognostic value of postoperative detection of blood circulating tumor cells in patients with colorectal cancer operated on for cure. Ann Surg 237: 368-375

Dubuisson L, Monvoisin A, Nielsen BS, Le Bail B, Bioulac-Sage P, Rosenbaum J (2000) Expression and cellular localisation of the urokinase-type plasminogen activator and its receptor in human hepatocellular carcinoma. J Pathol 190: 190 - 195

Hardingham JE, Hewett PJ, Sage RE, Finch JL, Nuttall JD, Kotasek D, Dobrovic A (2000) Molecular detection of blood-borne epithelial cells in colorectal cancer patients and in patients with benign bowel disease. Int $J$ Cancer 89: 8-13

Heiss MM, Allgayer H, Gruetzner KU, Babic R, Jauch KW, Schildberg FW (1997) Clinical value of extended biologic staging by bone marrow micrometastases and tumor-associated proteases in gastric cancer. Ann Surg 226: 736-744; discussion $744-5$

Heiss MM, Allgayer H, Gruetzner KU, Funke I, Babic R, Jauch KW, Schildberg FW (1995) Individual development and uPA-receptor expression of disseminated tumour cells in bone marrow: a reference to early systemic disease in solid cancer. Nat Med 1: 1035-1039

Heiss MM, Simon EH, Beyer BC, Gruetzner KU, Tarabichi A, Babic R, Schildberg FW, Allgayer H (2002) Minimal residual disease in gastric cancer: evidence of an independent prognostic relevance of urokinase receptor expression by disseminated tumor cells in the bone marrow. J Clin Oncol 20: 2005-2016 
Hellman S (1997) Stopping metastases at their source. N Engl J Med 337: 996- 997

Hildenbrand R, Glienke W, Magdolen V, Graeff H, Stutte HJ, Schmitt M (1998) Urokinase receptor localization in breast cancer and benign lesions assessed by in situ hybridization and immunohistochemistry. Histochem Cell Biol 110: 27 -32

Iinuma H, Okinaga K, Egami H, Mimori K, Hayashi N, Nishida K, Adachi M, Mori M, Sasako M (2006) Usefulness and clinical significance of quantitative real-time RT-PCR to detect isolated tumor cells in the peripheral blood and tumor drainage blood of patients with colorectal cancer. Int J Oncol 28: 297 - 306

Ikeguchi M, Kaibara N (2005) Detection of circulating cancer cells after a gastrectomy for gastric cancer. Surg Today 35: 436-441

Jauch KW, Heiss MM, Gruetzner U, Funke I, Pantel K, Babic R, Eissner HJ, Riethmueller G, Schildberg FW (1996) Prognostic significance of bone marrow micrometastases in patients with gastric cancer. J Clin Oncol 14: $1810-1817$

Kook YH, Adamski J, Zelent A, Ossowski L (1994) The effect of antisense inhibition of urokinase receptor in human squamous cell carcinoma on malignancy. EMBO J 13: 3983-3991

Laufs S, Schumacher J, Allgayer H (2006) Urokinase-receptor (u-PAR): an essential player in multiple games of cancer: a review on its role in tumor progression, invasion, metastasis, proliferation/dormancy, clinical outcome and minimal residual disease. Cell Cycle 5: 1760-1771

Lecomte T, Berger A, Zinzindohoue F, Micard S, Landi B, Blons H, Beaune P, Cugnenc PH, Laurent-Puig P (2002) Detection of free-circulating tumor-associated DNA in plasma of colorectal cancer patients and its association with prognosis. Int J Cancer 100: $542-548$

Mancuso P, Burlini A, Pruneri G, Goldhirsch A, Martinelli G, Bertolini F (2001) Resting and activated endothelial cells are increased in the peripheral blood of cancer patients. Blood 97: 3658-3661

Marutsuka T, Shimada S, Shiomori K, Hayashi N, Yagi Y, Yamane T, Ogawa M (2003) Mechanisms of peritoneal metastasis after operation for non-serosa-invasive gastric carcinoma: an ultrarapid detection system for intraperitoneal free cancer cells and a prophylactic strategy for peritoneal metastasis. Clin Cancer Res 9: $678-685$

Masuda TA, Inoue H, Sonoda H, Mine S, Yoshikawa Y, Nakayama K, Nakayama K, Mori M (2002) Clinical and biological significance of Sphase kinase-associated protein 2 (Skp2) gene expression in gastric carcinoma: modulation of malignant phenotype by Skp2 overexpression, possibly via p27 proteolysis. Cancer Res 62: 3819-3825

Masuda TA, Kataoka A, Ohno S, Murakami S, Mimori K, Utsunomiya T, Inoue H, Tsutsui S, Kinoshita J, Masuda N, Moriyama N, Mori M (2005) Detection of occult cancer cells in peripheral blood and bone marrow by quantitative RT-PCR assay for cytokeratin-7 in breast cancer patients. Int J Oncol 26: $721-730$

Mimori K, Fukagawa T, Kosaka Y, Kita Y, Ishikawa K, Etoh T, Iinuma H, Sasako M, Mori M (2008) Hematogenous metastasis in gastric cancer requires isolated tumor cells and expression of vascular endothelial growth factor receptor-1. Clin Cancer Res 14: 2609-2616

Mori M, Mimori K, Inoue H, Barnard GF, Tsuji K, Nanbara S, Ueo H, Akiyoshi T (1995) Detection of cancer micrometastases in lymph nodes by reverse transcriptase-polymerase chain reaction. Cancer Res 55: $3417-3420$

Mori M, Mimori K, Ueo H, Karimine N, Barnard GF, Sugimachi K, Akiyoshi $\mathrm{T}$ (1996) Molecular detection of circulating solid carcinoma cells in the peripheral blood: the concept of early systemic disease. Int J Cancer 68: $739-743$

Mori M, Mimori K, Ueo H, Tsuji K, Shiraishi T, Barnard GF, Sugimachi K, Akiyoshi T (1998) Clinical significance of molecular detection of carcinoma cells in lymph nodes and peripheral blood by reverse transcription-polymerase chain reaction in patients with gastrointestinal or breast carcinomas. J Clin Oncol 16: 128-132

Natsugoe S, Nakashima S, Nakajo A, Matsumoto M, Okumura H, Tokuda K, Miyazono F, Kijima F, Aridome K, Ishigami S, Takao S, Aikou T (2003) Bone marrow micrometastasis detected by RT-PCR in esophageal squamous cell carcinoma. Oncol Rep 10: $1879-1883$

Nielsen TO, Andrews HN, Cheang M, Kucab JE, Hsu FD, Ragaz J, Gilks CB, Makretsov N, Bajdik CD, Brookes C, Neckers LM, Evdokimova V, Huntsman DG, Dunn SE (2004) Expression of the insulin-like growth factor I receptor and urokinase plasminogen activator in breast cancer is associated with poor survival: potential for intervention with 17allylamino geldanamycin. Cancer Res 64: 286-291

Peters BA, Diaz LA, Polyak K, Meszler L, Romans K, Guinan EC, Antin JH, Myerson D, Hamilton SR, Vogelstein B, Kinzler KW, Lengauer C (2005) Contribution of bone marrow-derived endothelial cells to human tumor vasculature. Nat Med 11: $261-262$

Pyke C, Graem N, Ralfkiaer E, Ronne E, Hoyer-Hansen G, Brunner N, Dano K (1993) Receptor for urokinase is present in tumor-associated macrophages in ductal breast carcinoma. Cancer Res 53: $1911-1915$

Sadahiro S, Suzuki T, Ishikawa K, Saguchi T, Maeda Y, Yasuda S, Makuuchi H, Yurimoto S, Murayama C (2005) Detection of carcinoembryonic antigen messenger RNA-expressing cells in portal and peripheral blood during surgery does not influence relapse in colorectal cancer. Ann Surg Oncol 12: 988 - 994

Sobin LH, Fleming ID (1997) TNM Classification of Malignant Tumors, fifth edition (1997). Union Internationale Contre le Cancer and the American Joint Committee on Cancer. Cancer 80: 1803-1804

Sugai H, Kono K, Takahashi A, Ichihara F, Kawaida H, Fujii H, Matsumoto Y (2004) Characteristic alteration of monocytes with increased intracellular IL-10 and IL-12 in patients with advanced-stage gastric cancer. J Surg Res 116: 277 - 287

Yamaguchi K, Takagi Y, Aoki S, Futamura M, Saji S (2000) Significant detection of circulating cancer cells in the blood by reverse transcriptasepolymerase chain reaction during colorectal cancer resection. Ann Surg 232: $58-65$ 